\title{
GENETIC CHARACTERIZATION OF CENTENNIAL OLIVE TREES FROM NORTHERN CHILE: THE CASE OF EXTRA VIRGIN OLIVE OIL FROM HUASCO IN THE PROCESS OF DESIGNATION OF ORIGIN
}

\author{
CARACTERIZACIÓN GENÉTICA DE OLIVOS CENTENARIOS DEL \\ NORTE DE CHILE: EL CASO DEL ACEITE DE OLIVA EXTRA VIRGEN DEL \\ HUASCO EN PROCESO DE DENOMINACIÓN DE ORIGEN
}

\author{
Roberto Contreras $^{1 *}$, Fernanda Aguayo ${ }^{1}$, Alexi Guerra ${ }^{1}$, Francisco Tapia ${ }^{2}$, Vincenzo Porcile $^{1}$ \\ ${ }^{1}$ Centro de Investigación para el Desarrollo Sustentable de Atacama (CRIDESAT), Universidad de \\ Atacama, Av. Copayapu 485, Copiapó-Chile. \\ ${ }^{2}$ Instituto de Investigaciones Agropecuarias, Centro Regional de Investigación Intihuasi, Colina San \\ Joaquín s/n, Apartado Postal 36 B, La Serena, Chile. \\ *Corresponding autor E-mail: roberto.contreras@uda.cl
}

\begin{abstract}
The olive variety called Sevillana de Azapa and Sevillana del Huasco was introduced in northern Chile more than 350 years ago by the Spaniards. These olive trees are evidence of an important historical production of olives in the Valleys of Azapa and Huasco. However, the genetic differences of this variety in populations of each valley and between olive trees commonly cultivated in Chile are still unknown. In order to obtain Denomination of Origin (DO) certification for the olive products made from this variety, a more accurate quality control method is required to properly distinguish raw material. Based on the use of ISSR and RAPD markers, the results of this study showed that Sevillana has a high genetic variation within each valley, but also a very low diversity between valleys. The high genetic variation within the population suggests that the individuals originated from vegetative parts of different mother plants, or were propagated by seeds. On the other hand, the populations of centennial trees of the Huasco and Azapa valleys are genetically distinct from the most important olive varieties marketed in the rest of Chile. It can be concluded the ISSR and RAPD markers can be used to characterize the raw material of Huasco olive oil with DO so as to differentiate this oil from other varieties established in the rest of the country.
\end{abstract}

Key words: RAPD, ISSR, DNA molecular markers, Azapa and Huasco Valleys, olive oil, designation of origin.

\section{RESUMEN}

La variedad de aceituna Sevillana de Azapa y Sevillana del Huasco se introdujo en el norte de Chile desde España hace más de 350 años. Estos olivos son evidencia de una importante producción histórica de aceitunas en los Valles de Azapa y Huasco. Sin embargo, hasta la fecha se desconocen las diferencias genéticas de esta variedad entre poblaciones de cada valle, como así también diferencias genéticas con olivos comúnmente cultivados en Chile. Debido a la aparición de propuestas para certificar con Denominación de Origen (DO) los productos olivícolas elaborados con esta variedad, se hace necesario un método más preciso de control de calidad para distinguir la materia prima. En este estudio, con los marcadores ISSR y RAPD se encontró evidencia de una alta variabilidad genética de la variedad Sevillana dentro de cada valle, pero a la inversa, se encontró una diversidad 
muy baja entre valles. Además, la alta variabilidad genética dentro de la población sugiere que los individuos se originaron a partir de partes vegetativas de diferentes plantas madres, o se propagaron por semillas. Por otro lado, las poblaciones de árboles centenarios de los valles Huasco y Azapa son genéticamente distintas de las variedades de aceituna más importantes comercializadas en el resto de Chile. En resumen, los marcadores ISSR y RAPD podrían ser una técnica viable para caracterizar la materia prima utilizada para producir aceite de oliva de Huasco con DO, con el fin de diferenciarla de otras variedades de aceite de oliva establecidas en el resto del país.

Palabras clave: RAPD, ISSR, marcadores moleculares de ADN, valles de Azapa y Huasco, aceite de oliva, denominación de origen.

\section{INTRODUCTION}

Olive oil consumption has risen steadily in recent years, primarily due to its beneficial health properties. The Mediterranean basin is both the main producer and consumer of olive oil, while Spain, Italy and Greece are recognized as the largest suppliers in the global market (Romo and Gil, 2015).

The world's production of olive oil reached about 2.53 million tons in 2016-2017. The European Union countries accounted for approximately $68.7 \%$, while neighboring countries, including Syria, Tunisia, Turkey, Morocco and Algeria, accounted for approximately 22\% (IOOC 2017). In this sense, less than $8 \%$ of this global production comes from countries as Chile, USA, Argentina, Australia, Palestine, Libya, Jordan, Israel and Egypt (IOOC 2017).

In Chile, olive oil production has increased exponentially in the last two decades, from 197 tons in 1997 to 19,000 tons in 2017 (ChileOliva 2015; IOOC 2017). The total area of olives under cultivation in Chile is 25,000 hectares, and includes the varieties Arbequina (57\%), Arbosana $(20 \%)$, Frantoio and Leccino (10\%), Picual (5\%), Koroneiki (3\%), Coratina (2\%), Oliana (1\%), and others (2\%) (ChileOliva 2015). A dual-purpose variety intended for both table and oil production is included in this $2 \%$. It was introduced by the Spaniards during the conquest, and locally called according to the area in which it was grown as either 'Sevillana del Huasco' or 'Sevillana de Azapa'.

According to the Catalog of International Olive Varieties, this variety is known internationally as 'Azapa' (Barranco et al., 2000). Azapa has characteristics that differentiate it from other olive varieties (Sotomayor 2000). In Chile, Azapa is marketed as Sevillana 'Tipo Azapa' and Sevillana 'Tipo Huasco' (Hashiguchi 2005).

'Azapa' was first introduced in Peru by Spanish settlers in 1560. Despite significant losses of the original plant propagative material during the journey (Molina 2015), trees were successfully established in the Azapa Valley in Peru, and subsequently in the Huasco Valley in
Chile (Hidalgo 1993). Regarding propagative techniques, anecdotal evidence indicates that in the American continent, including Chile, olives were primarily propagated by cuttings and shoots taken from the base of the tree, as well as by seeds and grafts (Molina 2015).

Morphological descriptors are commonly used to distinguish between species and varieties, but they have the disadvantage of being influenced by the environment (Busconi 2006; Ye et al., 2008). Polymerase Chain Reaction (PCR) and the development of the genetic fingerprint now allow for accurate identification of specific cultivars or clones (Busconi 2006). The most widely used molecular markers include SSR (Simple Sequence Repeat), AFLP (Amplified Fragment Length Polymorphism), RFLP (Restriction Fragment Length Polymorphism), RAPD (Random Amplification of Polymorphic), ISSR (Inter Simple Sequence Repeat), and SCAR (Sequence Characterize Amplified Regions) (Busconi, 2006; Pasqualone et al., 2007; Koehmstedt et al., 2010; Linos et al., 2014). Random amplified polymorphism DNA (RAPD) markers (Williams et al., 1990) are a promising marker system widely used in plant research, including phylogenetic studies, genetic mapping, DNA fingerprinting, plant breeding and germplasm management. This marker is useful for variety and cultivar analysis as it is simple, efficient, and capable of detecting relatively small amounts of genetic variation without the need for prior information on the genome. ISSR (Inter-simple sequence repeat) is based on the variation found in the regions between the microsatellites (Zietkiewicz et al., 1994), and like RAPD, has a wide range of uses in genetic analysis.

Correct genetic identity is considered a key quality factor in the olive production sector. For extra virgin olive oil from Huasco to be certified according to Designation of Origin (DO), olive growers in the area have determined that the 'Sevillana del Huasco' variety must be used in its production. According to the Chilean National Institute of Industrial Property (INAPI), one the most important requirements to obtain DO certification is that the characteristics of 
the product should be derived primarily or exclusively from its geographical origin (INAPI 2017a). Due to the wide range of propagative techniques employed, genetic differences between Azapa and Huasco trees are likely to be found, while there is uncertainty regarding the origins of these genotypes, which may, in fact, be clones derived from unrelated parental trees from Spain. Centennial olive trees from the Azapa and Huasco valleys (older than 350 years) are a globally unique resource and, therefore, a valuable raw material for olive oil production in the Huasco Valley (Romero et al., 2015).

The aim of this study was to evaluate cluster analysis and differences in genetic profiles between genotypes of centennial olive trees from the Azapa and Huasco valleys and in varieties commonly produced and marketed in Chile, as well as the genetic variability between and within the Huasco and Azapa populations. Ultimately, the objective is to test the technical ability of ISSR and RAPD markers to accurately identify the raw material base, Sevillana del Huasco olives, in extra virgin olive oil from the Huasco Valley in the Designation of Origin process.

\section{MATERIALS AND METHODS}

\section{Plant material}

Leaves from the middle portion of the canopies of 10 centennial olive trees each were collected from the Azapa (Azapa Olive Growers Association, Fig. 1) and Huasco Valleys (Fundo Olivos Centenarios Farm, managed by Mrs. Daisy Rojas, Fig. 2) in 2017. Based on information provided by ChileOliva (2015), several of the most widely marketed olive oil varieties in Chile were also evaluated for comparison. Accordingly, leaves of 10 of these varieties were collected: Arbequina, Arbosana, Barnea, Coratina, Empeltre, Frantoio, Koroneiki, Leccino, Liguria and Picual. Leaves of Sevillano INIA variety were also collected from the Olive Germplasm Bank at the INIA Huasco Experimental Station $\left(28^{\circ} 34^{\prime} 44.2^{\prime \prime} \mathrm{S} 70^{\circ} 47^{\prime} 53.8^{\prime \prime}\right.$ W) in Vallenar city (Table 1).

\section{DNA Extraction}

DNA extraction was performed according to the CTAB (cetyl trimethylammonium bromide) method proposed by Doyle and Doyle (1987), with modifications. An amount of 0.1 grams of leaf material of each variety was weighed, and liquid nitrogen was applied in a sterilized mortar. The material was homogenized by compaction until a fine powder was obtained. The homogenate was transferred to a $2 \mathrm{~mL}$ microcentrifuge tube and stored at $-80^{\circ} \mathrm{C}$. An amount of $100 \mathrm{mg}$ of homogenized powder was mixed with $700 \mu \mathrm{L}$ of CTAB solution (100 mM Tris- $\mathrm{HCl} \mathrm{pH} 8,1.4 \mathrm{M}$ $\mathrm{NaCl}, 20 \mathrm{mM}$ EDTA, 2\% CTAB) 2\% PVP-40 w/v preheated to $65^{\circ} \mathrm{C}$ for 15 minutes, along with $4 \mu \mathrm{L}$ of Proteinase K and $14 \mu \mathrm{L}$ of $\beta$-mercaptoethanol. The tubes were shaken in a Vortex (Scilogex) for $10 \mathrm{sec}$, and then incubated in a thermal bath at $65^{\circ} \mathrm{C}$ for $60 \mathrm{~min}$, inverting them every 15 minutes. Tubes were then centrifuged (Universal Centrifuge $320 \mathrm{R}$, Hettich, Germany) at 14,000 rpm for $10 \mathrm{~min}$ at $4^{\circ} \mathrm{C}$, and the resulting supernatant transferred to a new $2 \mathrm{~mL}$ tube. A volume of 700 $\mu \mathrm{L}$ of chloroform: isoamyl alcohol solution (24: 1 ) was added and mixed by gently inverting the tubes for $2 \mathrm{~min}$ at room temperature. Tubes were recentrifuged at $14,000 \mathrm{rpm}$ for $10 \mathrm{~min}$ at $4^{\circ} \mathrm{C}$, and the upper phase recovered and transferred to a $1.5 \mathrm{~mL}$ tube. Subsequently, a volume of 5 $\mu \mathrm{L}$ of $10 \mathrm{mg} / \mathrm{mL}$ of RNAse (Thermofisher) was added to the recovered volume (approximately $500 \mu \mathrm{L}$ ), and the mixture was incubated at $37^{\circ} \mathrm{C}$ for $30 \mathrm{~min}$. A proportional volume of $2 / 3$ was then added to the recovered volume in each isopropanol tube at $-20^{\circ} \mathrm{C}$ (for example, a volume of $333 \mu \mathrm{L}$ of isopropanol was added to a volume of $500 \mu \mathrm{L}$ ), and mixed by gently inverting the tubes 30 times at room temperature. The content was then transferred with a maximum volume of $650 \mu \mathrm{L}$ to a column with a silica membrane (DNACOL-02 OMEGA) and allowed to stand for $4 \mathrm{~min}$. Then it was centrifuged at 10,000 rpm for 1 min (Centrifuge 5424, Eppendorf, Germany) at room temperature $\left(\sim 20^{\circ} \mathrm{C}\right)$, and the liquid was subsequently discarded from the collection tube. The silica column was then washed with $600 \mu \mathrm{L}$ of $70 \% \mathrm{v} / \mathrm{v}$ alcohol solution and $10 \mathrm{mM}$ ammonium acetate, and centrifuged at 10,000 rpm for 1 min (Centrifuge 5424, Eppendorf, Germany) at room temperature; the liquid was discarded in the collection tube again. This operation was repeated one more time. The collection tube was then discarded, and a new $1.5 \mu \mathrm{L}$ tube was placed on the column. A volume of $30 \mu \mathrm{L}$ of TE buffer (10 mM Tris.HCl ph 7.8, 1 mM EDTA) was added to the silica membrane, and incubated at $36^{\circ} \mathrm{C}$ for $25 \mathrm{~min}$, followed by centrifugation at 14,000 rpm for $2 \mathrm{~min}$ (Centrifuge 5424, Eppendorf, Germany) at room temperature $\left(\sim 20^{\circ} \mathrm{C}\right)$. To evaluate the integrity of the DNA, a volume of $5 \mu \mathrm{L}$ of extract was run by electrophoresis with $2.5 \mu \mathrm{L}$ of bromophenol buffer in $1.2 \%$ agarose gel (Cleaver Scientific), while DNA concentration and contamination was evaluated using a COLIBRI microvolume spectrophotometer (TitertekBerthold, Pforzheim, Germany).

\section{ISSR amplification}

For ISSR amplification, the UBC826, UBC825 UBC810, UBC881, UBC807, UBC823 and UBC811 


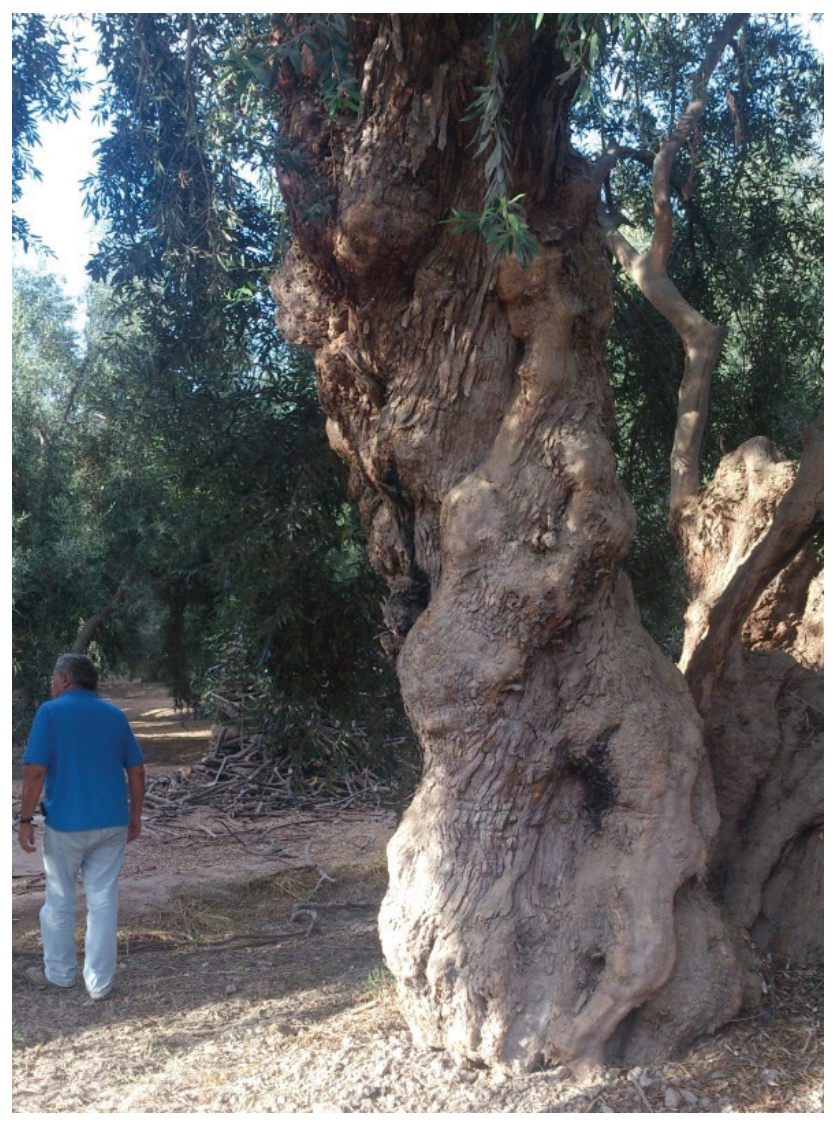

Fig. 1. Centennial olive tree (sample: Azapa 1) in Las Maitas, Azapa Valley.

Fig. 1. Olivo centenario (muestra: Azapa 1) ubicada en Las Maitas, Valle de Azapa.

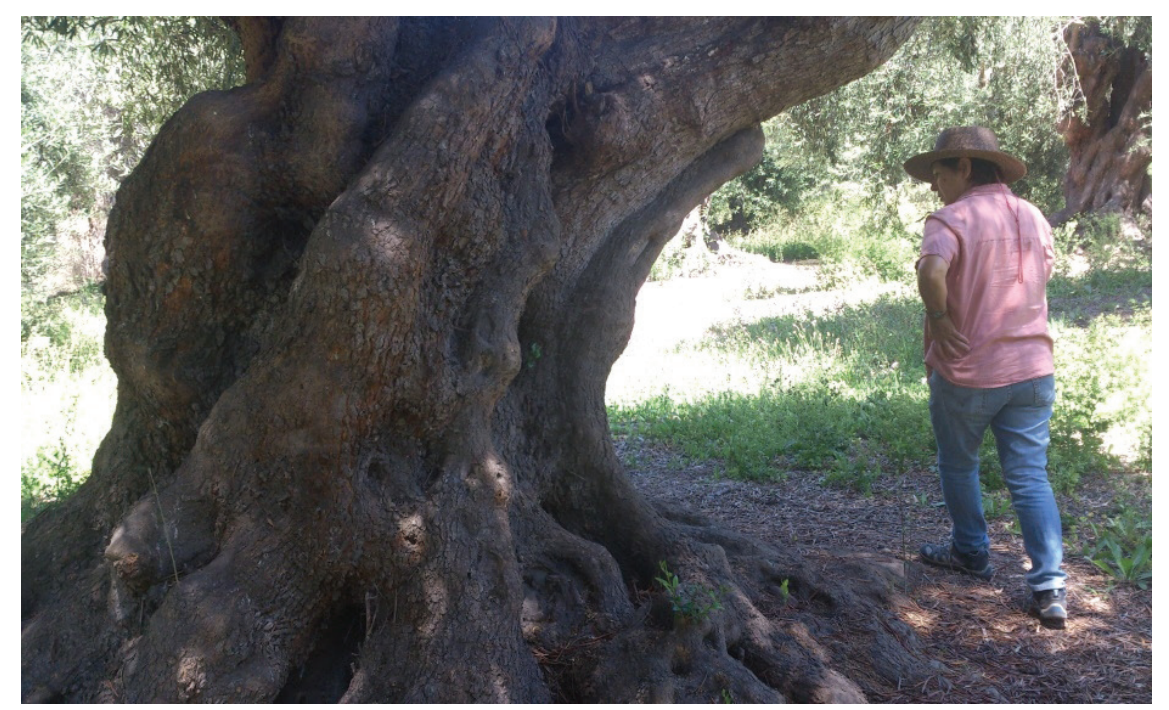

Fig. 2. Centennial olive tree (sample: Huasco 6) in the Las Quijadas sector, Fundo Olivo Centenario, Huasco Valley.

Fig. 2. Olivo centenario (muestra: Huasco 6) ubicado en el sector Las Quijadas, Fundo Olivo Centenario, Valle del Huasco. 
Table 1. Geographic coordinates and age of olive trees collected in northern Chile. Tabla 1. Coordenadas geográficas y edad de los olivos recolectados en el norte de Chile.

\begin{tabular}{|c|c|c|c|c|}
\hline Code & Nomenclature & Latitude & Longitude & Age (years) \\
\hline Azapa Cent 1 & Azapa $1\left(^{* * *}\right)$ & $18^{\circ} 30^{\prime} 38.9^{\prime \prime S}$ & $70^{\circ} 13^{\prime} 27.4^{\prime \prime W}$ & $\sim 382^{*}$ \\
\hline Azapa Cent 2 & Azapa 2 & $18^{\circ} 30^{\prime} 39.0^{\prime \prime S}$ & $70^{\circ} 13^{\prime} 27.2^{\prime \prime W}$ & $\sim 350^{*}$ \\
\hline Azapa Cent 3 & Azapa 3 & $18^{\circ} 30^{\prime} 39.1^{\prime \prime S}$ & $70^{\circ} 13^{\prime} 26.8^{\prime \prime W}$ & $\sim 366^{*}$ \\
\hline Azapa Cent 4 & Azapa 4 & $18^{\circ} 30^{\prime} 39.2^{\prime \prime S}$ & $70^{\circ} 13^{\prime} 26.5^{\prime \prime} \mathrm{W}$ & $\sim 380^{*}$ \\
\hline Azapa 236 & Azapa 5 & $18^{\circ} 32^{\prime} 35.9^{\prime \prime S}$ & $70^{\circ} 07^{\prime} 45.3^{\prime \prime} \mathrm{W}$ & $\sim 160^{*}$ \\
\hline Azapa 203 & Azapa 6 & $18^{\circ} 30^{\prime} 23.9^{\prime \prime S}$ & $70^{\circ} 12^{\prime} 31.0^{\prime \prime} \mathrm{W}$ & $\sim 132^{*}$ \\
\hline Azapa 229 & Azapa 7 & $18^{\circ} 30^{\prime} 11.7^{\prime \prime S}$ & $70^{\circ} 15^{\prime} 14.8^{\prime \prime} \mathrm{W}$ & $\sim 158^{*}$ \\
\hline Azapa 189 & Azapa 8 & $18^{\circ} 30^{\prime} 26.8^{\prime \prime S}$ & $70^{\circ} 12^{\prime} 29.4^{\prime \prime} \mathrm{W}$ & $\sim 154^{*}$ \\
\hline Azapa 273 & Azapa 9 & $18^{\circ} 30^{\prime} 58.6^{\prime \prime S}$ & $70^{\circ} 12^{\prime} 33.9^{\prime \prime} \mathrm{W}$ & $\sim 170^{*}$ \\
\hline Azapa Cent 5 & Azapa 10 & $18^{\circ} 30^{\prime} 39.2^{\prime \prime S}$ & $70^{\circ} 13^{\prime} 26.1^{\prime \prime W}$ & $\sim 345^{*}$ \\
\hline Las Quijadas 567 & Huasco 1 & $28^{\circ} 27^{\prime} 48.1^{\prime \prime S}$ & $71^{\circ} 11^{\prime} 10.4^{\prime \prime W}$ & $318-346^{* *}$ \\
\hline Las Quijadas 572 & Huasco 2 & $28^{\circ} 27^{\prime} 48.1^{\prime \prime S}$ & $71^{\circ} 11^{\prime} 11.4^{\prime \prime W}$ & $318-346^{* *}$ \\
\hline Las Quijadas 575 & Huasco 3 & $28^{\circ} 27^{\prime} 49.3^{\prime \prime S}$ & $71^{\circ} 11^{\prime} 12.7^{\prime \prime W}$ & $318-346^{* *}$ \\
\hline La Glorieta 582 & Huasco 4 & $28^{\circ} 27^{\prime} 48.8^{\prime \prime S}$ & $71^{\circ} 10^{\prime} 58.8^{\prime \prime W}$ & $200-260^{* *}$ \\
\hline La Glorieta 536 & Huasco 5 & $28^{\circ} 27^{\prime} 47.2^{\prime \prime S}$ & $71^{\circ} 10^{\prime} 54.8^{\prime \prime} \mathrm{W}$ & $200-260^{* *}$ \\
\hline Las Quijadas 565 & Huasco $6\left(^{(* * *}\right)$ & $28^{\circ} 27^{\prime} 48.1^{\prime \prime S}$ & $71^{\circ} 11^{\prime} 10.1^{\prime \prime W}$ & $318-346^{* *}$ \\
\hline Las Quijadas 573 & Huasco 7 & $28^{\circ} 27^{\prime} 48.2^{\prime \prime S}$ & 71¹'11.3"W & $318-346^{* *}$ \\
\hline Las Quijadas 578 & Huasco 8 & $28^{\circ} 27^{\prime} 50.2^{\prime \prime S}$ & 71¹1'13.6"W & $318-346^{* *}$ \\
\hline Las Quijadas 576 & Huasco 9 & $28^{\circ} 27^{\prime} 49.4^{\prime \prime S}$ & $71^{\circ} 11^{\prime} 12.7^{\prime \prime} \mathrm{W}$ & $318-346^{* *}$ \\
\hline Las Quijadas 574 & Huasco 10 & $28^{\circ} 27^{\prime} 49.7^{\prime \prime S}$ & 71'11'11.5"W & $318-346^{* *}$ \\
\hline Arbequina & Arbequina & & & \\
\hline Arbosana & Arbosana & & & \\
\hline Barnea & Barnea & & & \\
\hline Coratina & Coratina & & & \\
\hline Empeltre & Empeltre & $28^{\circ} 34^{\prime} 44.2^{\prime \prime} \mathrm{S}$ & $70^{\circ} 47^{\prime} 53.8^{\prime \prime} \mathrm{W}$ & $\sim 19$ \\
\hline Frantoio & Frantoio & 203444.25 & $304 / 33.0 \mathrm{Vv}$ & 19 \\
\hline Koroneiki & Koroneiki & & & \\
\hline Leccino & Leccino & & & \\
\hline Liguria & Liguria & & & \\
\hline Picual & Picual & & & \\
\hline Sevillana INIA & Sev-inia & & & \\
\hline
\end{tabular}

$\left(^{*}\right)$ Estimated age of olive trees based on trunk diameter measured at 1.3 meters from the ground. Age $=(2.11 \mathrm{x}$ diameter $(\mathrm{cm})+88.93$, calculation made by Arnan et al. (2012).

$\left.{ }^{* *}\right)$ Age of olive trees according to a dendrochronological study carried out by the University of Concepción.

$\left.{ }^{* * *}\right)$ Figure 1

$(* * *)$ Figure 2

(University of British Columbia) markers were selected based on the greater number of PCR bands and greater reproducibility according to Martins-Lopes et al. (2007). The $18 \mu \mathrm{L}$ PCR reaction consisted of: $9 \mu \mathrm{L}$ Master Mix DreamTaq (Thermo Fisher), $4 \mu \mathrm{L}$ of ISSR primer $(5 \mu \mathrm{M})$ and 5 $\mu \mathrm{L}$ of genomic DNA (2 ng/ $\mu \mathrm{L})$. The amplifications were performed in a Swift Max Pro thermocycler (ESCO, Singapore) under the following conditions (according to Claros et al., 2000, with minimal modifications): an initial step of $5 \mathrm{~min}$ at $94^{\circ} \mathrm{C}, 45$ cycles of 30 seconds at $94^{\circ} \mathrm{C}, 45$ seconds at $52^{\circ} \mathrm{C}$, and 2 minutes at $72^{\circ} \mathrm{C}$, followed by a final extension step of 6 minutes at $72^{\circ} \mathrm{C}$. The patterns generated by each ISSR primer were tested in duplicate before beginning the study (both in samples composed of three individuals as well as independent samples). This was done in order to observe its reproducibility and consistency in agarose gel at $1.7 \%$, in TBE $0.5 \mathrm{x}$ for $2 \mathrm{~h}$ at $100 \mathrm{~V}$ and stained with ethidium bromide. The gel was placed in a UV transilluminator (ilber Lourmat) and photographed with a digital camera (Canon, SX160 IS) for further analysis. 


\section{RAPD amplification}

For RAPD amplification, OPA-19 and OPC09 markers were selected based on the greater number of PCR bands and greater reproducibility according to Belaj et al. (2004). The $24 \mu \mathrm{L}$ PCR reaction consisted of: $12 \mu \mathrm{L}$ Master Mix SapphireAmp Fast PCR (Clontech), $4.8 \mu \mathrm{L}$ of primer, $2 \mu \mathrm{L}$ of genomic DNA $(2 \mathrm{ng} / \mu \mathrm{L})$, and $5.2 \mu \mathrm{L}$ of nuclease-free water. Amplifications were performed in a Swift Max Pro thermociller (ESCO) under the following conditions: an initial step of $1 \mathrm{~min}$ at $91^{\circ} \mathrm{C}, 35$ cycles of 1 minute at $94^{\circ} \mathrm{C}$, 1 minute at $36^{\circ} \mathrm{C}$ and 1 minute, and 30 seconds at $72^{\circ} \mathrm{C}$, followed by a final extension step of 2 minutes at $72^{\circ} \mathrm{C}$. Prior to the start of the study, the patterns generated by each RAPD primer were tested in duplicate, in samples composed of three individuals as well as independent samples. This was done in order to observe its reproducibility and consistency in agarose gel at $1.7 \%$, in TBE $0.5 \mathrm{x}$ for $2 \mathrm{~h}$ at $100 \mathrm{~V}$ and stained with ethidium bromide. The gel was placed in a UV transilluminator and photographed with a digital camera (Canon, SX160 IS).

\section{Morphological characterization of olives}

By the end of May 2017, a total of 25 fruits from 25 trees were collected from Huasco and Azapa valleys. For each fruit, the base-to-apex length and equatorial diameter were measured.

\section{Statistical analysis}

Each ISSR and RAPD band was considered an independent character, or locus, and polymorphic bands were scored as either presence (1) or absence (0) for each individual. Three independent scores were performed for each gel, and only bands that scored consistently were considered for analysis. The binary matrix was applied to determine corrected allele frequency based on Lynch and Milligan (1994). Jaccard's coefficient of similarity was calculated. Based on the matrix of genetic similarity, cluster analyses were performed using UPGMA and Neighbor joining with PAST program (Hammer et al., 2001), while bootstraps with 1,000 replicates were performed to test the robustness of dendrograms. In addition, Principal Component Analysis (PCA) was performed, also using the PAST program, for the clustering analyses of individual olives. To evaluate percent distribution of genetic variation among and within populations, an analysis of molecular variance (AMOVA) was performed using GenAlEx 6.5 software (Peakall and Smouse, 2012). Ten centennial trees per population (Azapa and Huasco) were analyzed according to data from previous studies described by Gemas et al. (2004) and Noormohammadi et al. (2012).
Twenty-five fruits were randomly selected from twenty-five trees from the Huasco and Azapa valleys. Maximum base-to-apex length $(\mathrm{cm})$ and equatorial diameter $(\mathrm{cm})$ were measured using vernier calipers. A Student's t-test $(p<0.05)$ was applied to determine significant differences in length and equatorial diameter between fruits from the different valleys.

\section{RESULTS AND DISCUSSION}

ISSR and RAPD markers were used to determine the genetic profiles for 10 of the most widely marketed olive oil varieties in Chile, as well as samples from centennial trees from Azapa and Huasco valleys (10 samples from each valley) (Table 1). These varieties are generally distinguishable based on the characteristics of their fruit. However, it is important to evaluate techniques, such as molecular DNA markers, that can be used when greater identification accuracy is required. In a previous study, the genetic profile of the INIA Sevillana variety (Azapa) was compared to six olive varieties based on the ISSR marker (Contreras and Tapia, 2016), confirming the validity of the method to differentiate the Sevillana variety (Azapa). To date, however, there is no research comparing the Sevillana variety, either from Huasco or Azapa valleys, with other varieties of high commercial interest established in Chile.

In this study, 120 PCR fragments comprising seven ISSRs, and 25 fragments comprising two RAPDs were obtained, yielding an average of 17.1 and 12.5 ISSR and RAPD fragments, respectively. Based on these data, a relatively high range of similarity values (between 0.72 0.96) were observed between Azapa and Huasco tree genotypes. Conversely, low similarity values (between 0.28-0.52) were found between oil varieties and Azapa-Huasco. Centennial trees Azapa 2 and Huasco 2 generated the highest similarity value (0.96), while Huasco 3 and Koroneiki generated the lowest value (0.28).

Fig. 3 shows a UPGMA dendrogram constructed with Jaccard's distance, showing two main clusters: Cluster 1 and Cluster 2. The same clustering results were observed by principal component analysis (PCA, Fig. 4) and a Neighbor joining dendogram (data not shown). All Huasco and Azapa centennial trees are clearly grouped in Cluster 1, while the Sev-INIA sample, forms a separate group (Fig. 3). According to INIA, while the Sev-INIA sample is a similar genotype to the Huasco and Azapa centennial trees, its genetic relationship is perhaps more distant, because it would have originated as a cross with local olive varieties. On the other hand, the method detected significant 


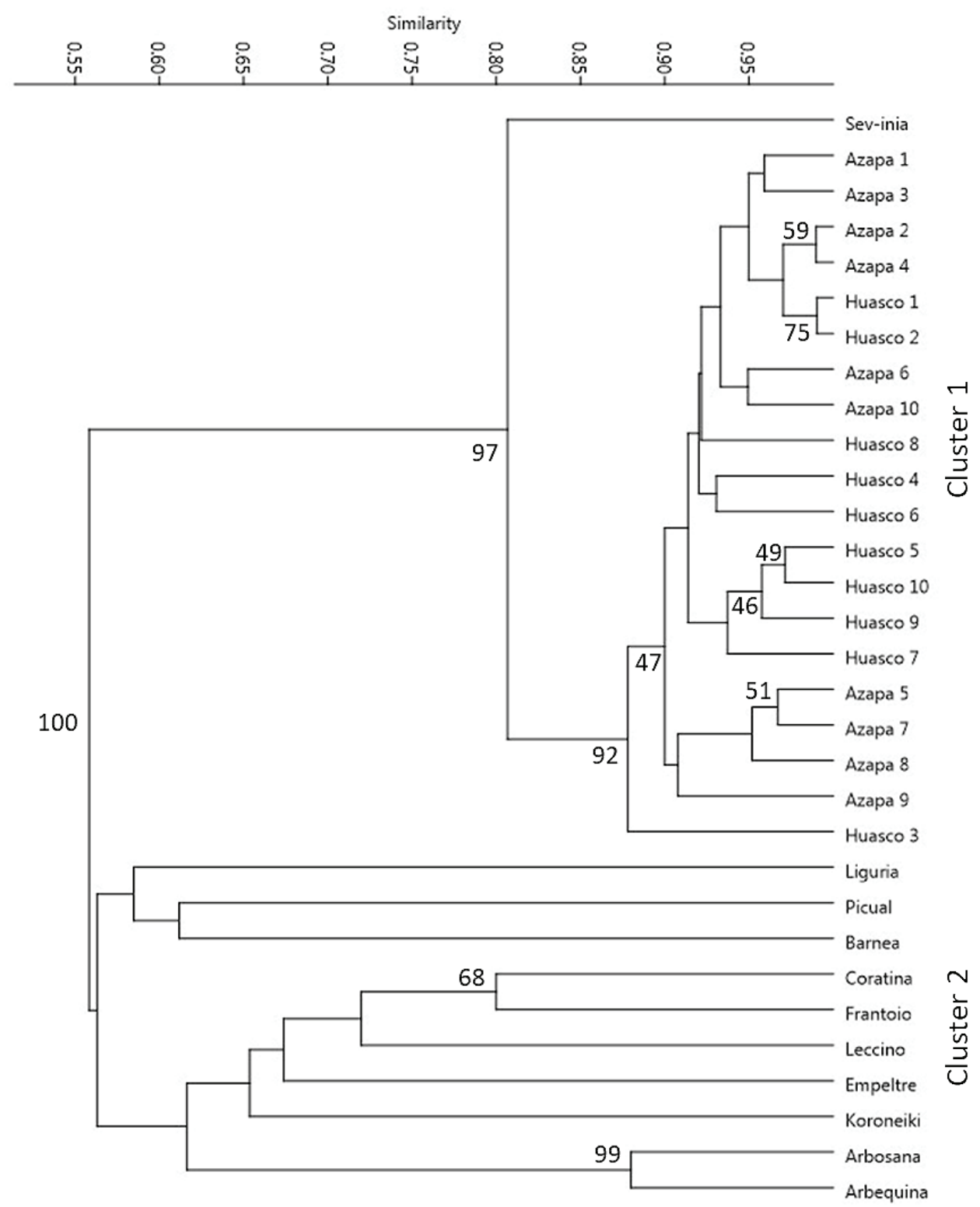

Fig. 3. UPGMA cluster analysis according to Jaccard similarity, calculated based on $\mathbf{1 4 5}$ markers obtained from ISSR and RAPD. Bootstrap value percentages above 46 are indicated.

Fig. 3. Análisis de conglomerados UPGMA según la similitud de Jaccard, calculado a partir de $\mathbf{1 4 5}$ marcadores obtenidos de ISSR y RAPD. Están indicados los porcentajes de valor Bootstrap por encima de 46 .

differences in PCR genetic patterns between Huasco-Azapa and commercialized oil varieties (Fig. 5). This shows the importance of genetic identification of olive trees in terms of detection of original genotypes.

Regarding the Azapa and Huasco trees grouped in Cluster 1, Huasco 3 genotype is clearly distinct from the other 19 individuals. This genotype shows differences in genetic profile, based on the UBC $810\left(\mathrm{GA}_{8} \mathrm{~T}\right)$ and UBC811 $\left(\mathrm{GA}_{8} \mathrm{C}\right)$ markers, compared to the rest of the Huasco and Azapa trees (see Fig. 5). To improve identification precision, the SCAR technique could be used to validate Huasco 3 fragments, and identify the olives used to make Huasco olive oil. If this variation is confirmed, growers in the Huasco Valley could multiply Huaco 3 genotype for DO using cuttings or grafts in the next planting 


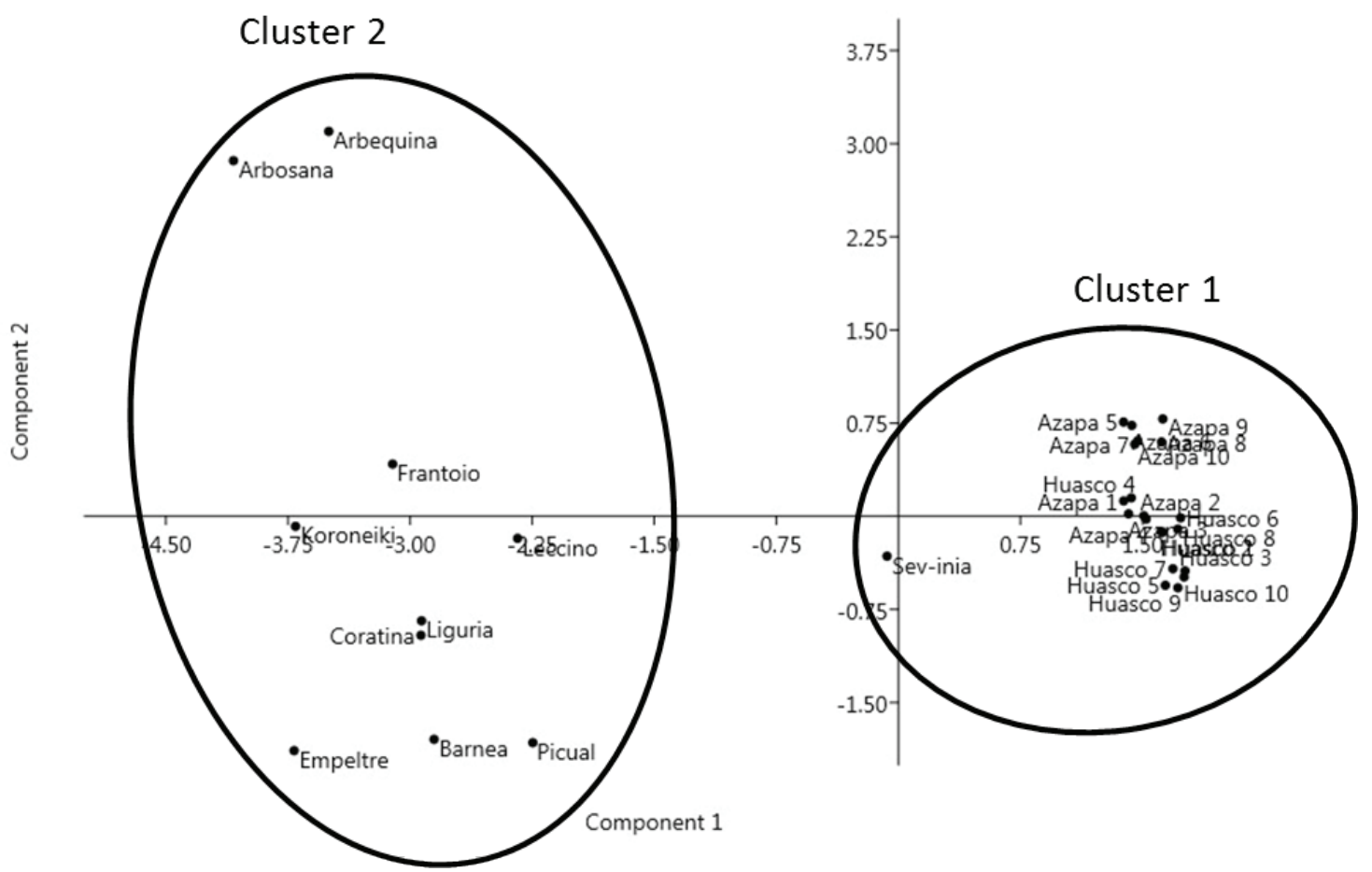

Fig. 4. Principal Component Analysis based on ISSR and RAPD markers, and the Jaccard similarity index among 10 common oil varieties, 20 centennial olives from Huasco and Azapa Valley and the variety Sevillana INIA. The first and second principal components account for $38.98 \%$ and $8.72 \%$ of the genetic variation, respectively.

Fig. 4. Análisis de componentes principales basado en marcadores ISSR y RAPD y el índice de similitud Jaccard entre 10 variedades de aceite comunes, 20 olivas centenarias de Huasco y Valle de Azapa y la variedad Sevillana INIA. El primero y el segundo componentes principales representan el $38,98 \%$ y el $8,72 \%$ de la variación genética, respectivamente.

program. Within Cluster 1, genotypes Azapa 5, Azapa 7, Azapa 8 and Azapa 9 formed other significant groupings separate from the other 15 Huasco and Azapa trees (Fig. 3). Three other significant groupings were detected, comprising trees Huasco 5 and Huasco 10, Huasco 1 and Huasco 2, and Azapa 2 and Azapa 4. Therefore, it is evident that Huasco and Azapa trees tend to form distinct groups, with fewer groupings comprising both genotypes.

By comparing widely marketed olive oil varieties with centennial trees from Huasco and Azapa, the precision of genetic characterization was put to the test using ISSR and RAPD molecular markers. There are several studies on genetic characterization of olive trees with ISSR and RAPD markers, carried out mainly in countries in the Mediterranean basin (Claros et al., 2000; Sesli and Yegenoglu, 2017, Linos et al., 2014, MartinsLopes et al., 2007). As observed in Figs. 3 and 4, centennial olive trees of Huasco and Azapa are distinct from all other oil varieties. Cluster 2 in Fig. 3 is divided into several subgroups, with the subgroups comprising Arbosana and Arbequina, being significantly valid (bootstrap greater than 50), and also the subgroup comprising Coratina and Frantoio. Montemurro et al. (2005) reported the same trend of grouping between the Italian Frantoio and Coratina varieties by using the UPGMA dendrogram from data with AFLP and SSR markers. Likewise, Koehmstedt et al. (2010) observed grouping between the Spanish varieties Arbequina and Arbusana by means of a UPGMA dendrogram constructed with SSR markers and concentrated in Group 2 (cluster C12). Therefore, the results in grouping obtained with the ISSR and RAPD markers in this study (Fig. 3) are in agreement with those reported in earlier studies.

The genetic variability of fruit trees must be controlled from the beginning in order to achieve uniform yields. For this reason, it is inappropriate to establish an olive orchard with trees obtained 

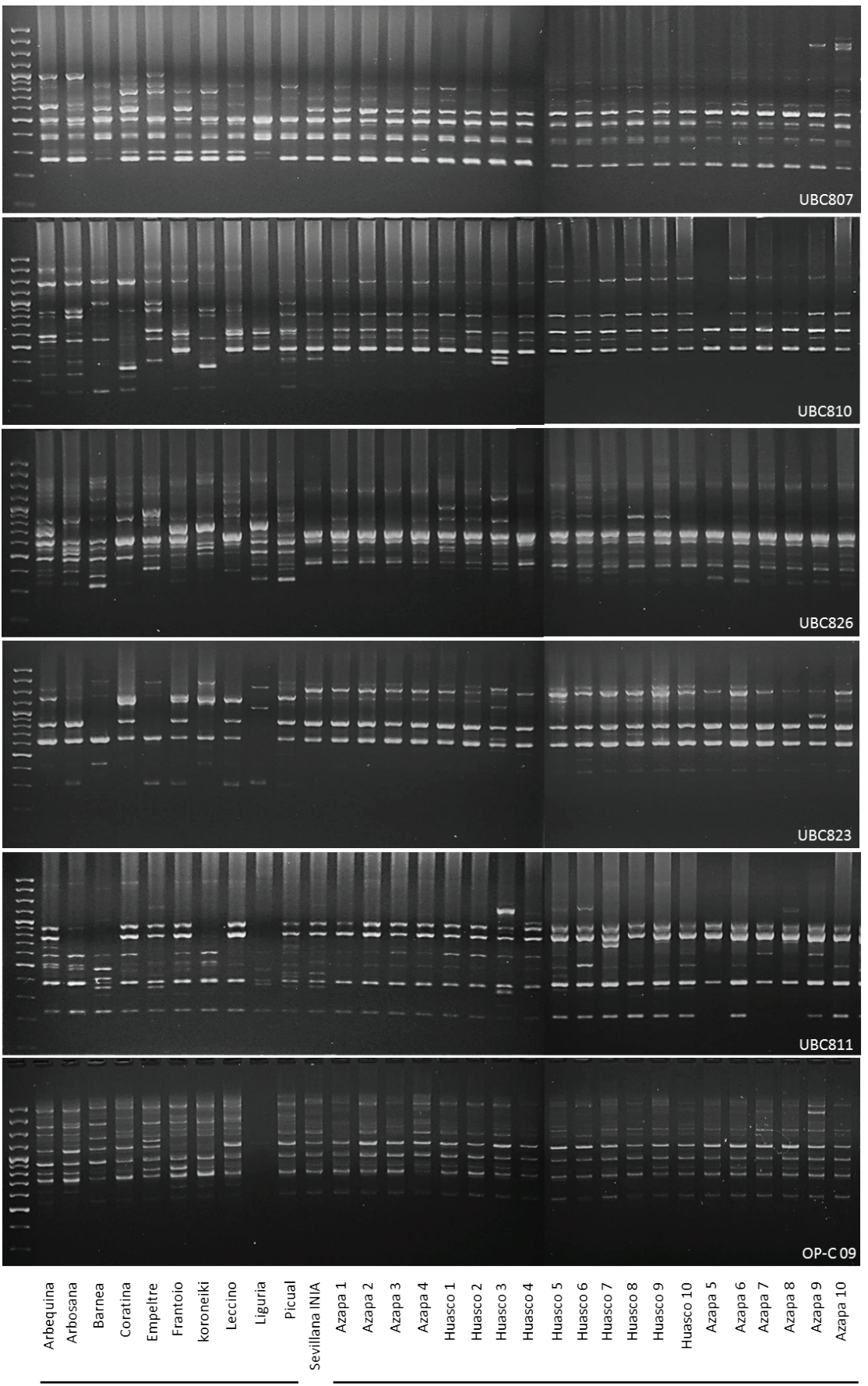

Common oil varieties

Ancient Sevillanas from Huasco and Azapa

Fig. 5. Electrophoresis pattern obtained on agarose gel using ISSR (UBC823, UBC807, UBC810, UBC826, UBC823 and UBC811) and RAPD (OP-C 09) primers with eleven common olive oil varieties (Arbequina, Arbosana, Barnea, Coratina, Empeltre, Frantoio, Koroeniki, Leccino, Liguria, Picual and Sevillana INIA) and centennial Sevillanas from Huasco and Azapa. First lane is a DNA ladder ranged 100-3000 bp. For a complete visualization of PCR profiles, two agarose gels of 20 and 12 wells were linked.

Fig. 5. Patrón de electroforesis obtenido en gel de agarosa usando cebadores ISSR (UBC823, UBC807, UBC810, UBC826, UBC823 y UBC811) y RAPD (OP-C 09) con once variedades comunes de aceite de oliva (Arbequina, Arbosana, Barnea, Coratina, Empeltre, Frantoio, Koroeniki, Leccino, Liguria, Picual y Sevillana INIA) y sevillanas centenarias de Huasco y Azapa. El primer carril es un marcador de ADN de 100-3000 pb. Para una visualización completa de los perfiles de PCR, fueron unidos dos geles de agarosa de 20 y 12 pocillos. 
from different propagation techniques (stake, graft or seeds). Asexual techniques (cuttings and grafts) ensure a genetically identical generation to the original plant material, with similar agronomic traits under similar environments, but this is not the case for sexual propagation techniques (seed). Information regarding the propagation of Azapa and Huasco centennial trees, either by graft, seed or cuttings, is currently limited, while genetic differences are likely to occur in clones within the same population. The genetic differences between Azapa and Huasco centennial trees (Fig. 3) found in this study may be due to the fact that they originate from different sources of propagation material. Molecular techniques based on ISSR and RAPD markers are essential because they allow the identification of individuals. In the case of the olive industry, clonal genotypic characteristics can be contrasted with important agronomic variables, such as yield, resistance to diseases, and tolerance to abiotic stress, among others.

A molecular analysis of variance AMOVA was performed to analyze the intra and interpopulation variation of Huasco and Azapa centennial trees. Low levels of genetic variability were observed between them (Table 2). Although most of the total genetic diversity was attributed to differences between individuals within populations $(79 \%, \mathrm{P}<0.001)$, the results show that there is no significant genetic variation between Azapa and Huasco centennial trees $(21 \%, \mathrm{P}<$ 0.001). Although this was an expected result (Hidalgo, 1993; Molina, 2015), to date there is no genetic study to confirm this finding.

Genotypes from Huasco and Azapa are similar, but they present differences in fruit size. The average length of olives from Azapa is significantly higher $(p<0.05)$ than fruit from the Huasco Valley, with average values of 3.23 $\mathrm{cm}$ and $2.67 \mathrm{~cm}$, respectively (Fig. 6A). At an average of $2.25 \mathrm{~cm}$, fruit diameter in Azapa is significantly greater $(p<0.05)$ than in Huasco, with an average diameter of $1.98 \mathrm{~cm}$ (Fig. 6B). Even though these results indicate that fruit from Azapa is significantly larger than that from Huasco, these data may not be conclusive, since fruit size may be influenced by a range of factors, such as harvest season and agricultural practices (e.g. fertilization, pruning, irrigation etc.) (Tapia et al., 2003). In this study, this was considered to design the sampling strategy for each zone so as to identify plots subject to similar agricultural management practices.

A fundamental biological principle explains that phenotype is the result of interaction between genotype and environment. The phenotype is the total sum of of the visible or measurable characteristics of an organism that define it as an individual (e.g. fruit size, tolerance to stress and disease, phenological stages, etc.) (Fabbri et al., 2004). When the same genotypes are subject to different environments, they can produce a wide range of phenotypes (Baye et al., 2011). In this sense, a study conducted by Padula et al. (2008), in which several olive genotypes were established in different climates, showed that environmental effects were more important than genotype in terms of average fruit weight and oil content of fresh base material. Based on this, the difference in fruit size between Azapa and Huasco individuals (Fig. 6) can be attributed to environmental characteristics rather than genotype, considering the low levels of genetic variability between the two populations observed in the AMOVA (Table 2). In fact, distinct climatic (environmental temperature) and pedological conditions (salinity and $\mathrm{pH}$ of soil) are observed in both valleys (Antúnez et al., 2014; Tapia et al., 2003). As for the temperature effect in olive fruit size, PérezLópez et al. (2007) observed an increase in the longitudinal diameter of olive fruit, which was dependent on temperature. In addition, Barasani et al. (2017) found variation in olive phenotypic traits influenced by different environmental conditions. Moreover, Tapia et al. (2003) also indicated that environmental temperature is one of the most important factors affecting the development of olives. Local processing and packaging companies have already observed

Table 2. Analysis of molecular variance (AMOVA) between Sevillana del Huasco and Sevillana de Azapa tree populations $(P<0.001)$.

Tabla 2. Análisis de varianza molecular (AMOVA) entre las poblaciones de árboles de Sevillana del Huasco y Sevillana de Azapa $(P<0,001)$.

\begin{tabular}{lccccc}
\hline $\begin{array}{l}\text { Source of } \\
\text { variation }\end{array}$ & df & $\begin{array}{c}\text { Sum of } \\
\text { squares }\end{array}$ & $\begin{array}{c}\text { Mean } \\
\text { square }\end{array}$ & $\begin{array}{c}\text { Variance } \\
\text { component }\end{array}$ & $\begin{array}{c}\% \text { total } \\
\text { variance }\end{array}$ \\
\hline Among Pops & 1 & 14.350 & 14.350 & 1.050 & $21 \%$ \\
Within Pops & 18 & 69.300 & 3.850 & 3.850 & $79 \%$ \\
Total & 19 & 83.650 & & 4.900 & $100 \%$ \\
\hline
\end{tabular}



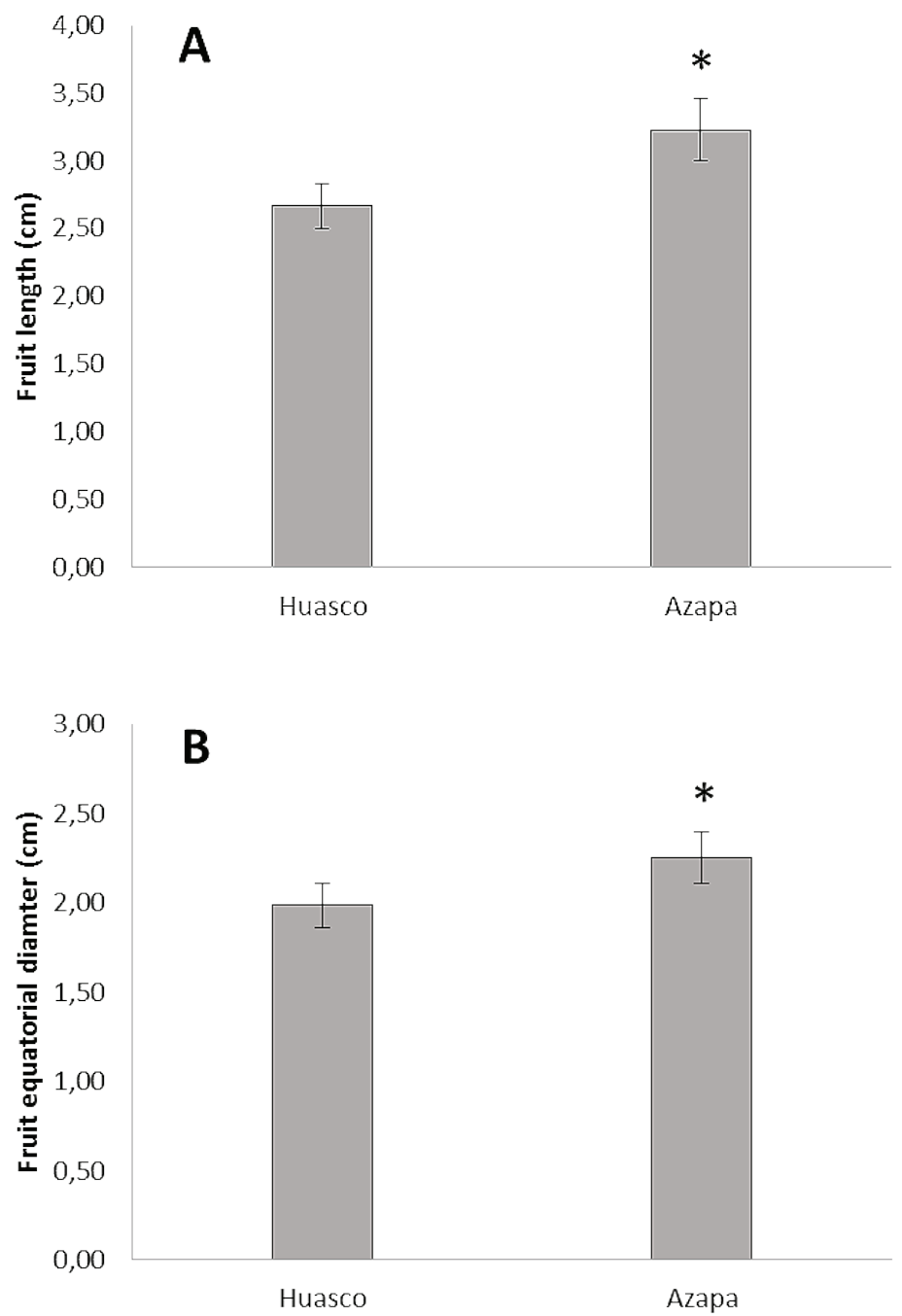

Fig. 6. Average values of A) fruit length, and B) equatorial diameter of olives from centennial trees from the Huasco and Azapa Valleys. Values are given as the average \pm S.E.M from twentyfive fruits. Significant values were detected by Student's $t$ test, and are identified by a single asterisk $(\mathrm{p}<0.05)$.

Fig. 6. Valores promedio de A) longitud del fruto, y B) diámetro ecuatorial de las aceitunas de árboles centenarios de los valles de Huasco y Azapa. Los valores se dan como el promedio \pm S.E.M de veinticinco frutos. Los valores significativos se detectaron mediante la prueba $t$ de Student, y se identifican con un solo asterisco $(p<0,05)$.

differences in fruit size, referring generically to smaller fruit as the "Huasco type" and larger fruit as "Azapa type". According to distributors, market demand is higher for Azapa type olives because of their larger size and, therefore, olive growers in Huasco face the challenge of increasing the size of their olives (Hashiguchi, 2005).

Huasco Valley (Atacama Region) currently produces the only extra virgin olive oil subject to Designation of Origin (DO) in Chile. According to olive growers' regulations, this oil should consist of a minimum of $10 \%$ of the Sevillana del Huasco variety (INAPI 2017b). According to the DO of olive oil from Huasco, variety differentiation is currently based on the particular characteristics of each variety, depending on their total polyphenol content (Fuentes et al., 2018; Romero et al., 2015). Tapia et al. (2015) analyzed olive oil blends from mixtures of Arbequina and Frantoio varieties and base varieties of the Sevillana del 
Huasco, and concluded that these oils yield unique and irreproducible chemical, sensory and functional characteristics that are not found in any other olive-growing area of Chile. To ensure the quality of the final DO product, Tapia et al. (2015) proposed to certify the raw material used in each producer's formulation, as required by the regulation of use and control. Some olive oil products from Italia have obtained protected designation of origin (PDO) at a European level; in order to avoid possible mixture or substitutions of raw materials, SSR molecular markers are used to distinguish cultivars (Pasqualone et al., 2007; Montemurro et al., 2015). In Portugal, markers for varietal certification purposes were identified in the ancient cultivar Gallega, which is used to produce oil with PDO, using ISSR and RAPD molecular markers (Gemas et al., 2004). Genetic characterization of the raw material (fruit) should be the baseline for the protocols described in this study, involving differentiation of the genetic profiles of the different varieties based on the majority of molecular markers tested (Fig. 5). As shown by Contreras and Tapia (2016), leaf and fruit genetic profiles in the same variety are similar. Therefore, ISSR and RAPD molecular markers allow the accurate determination of the olive variety used in the production of extra virgin olive oil from Huasco, distinguishing this variety from others commonly used in Chile. This is key point to support the process of designation of origin of olive oil produced in the Huasco Valley.

\section{CONCLUSION}

ISSR and RAPD markers demonstrated that the populations of centennial trees of Huasco and Azapa valleys are separated from trees of the most important olive oil varieties established and marketed in Chile. Similarly, the method showed notable differences in PCR genetic patterns between the Huasco-Azapa varieties. Based on genetic relationships, it was possible to identify differences between an individual from Huasco (Huasco 3) and Azapa trees. This may potentially represent a characteristic genotype of that area, but a larger sample size would be required to confirm this. There is evidence of high intra-population variability among the centennial olive populations of Huasco and Azapa, but variability between populations was very low. As anticipated, this is evidence of similarity between Azapa and Huasco individuals. However, high genetic variability within each population suggests that individuals originate from plant parts of different mother plants or are propagated by seed. Given the genetic similarity of Huasco and Azapa varieties, size differences in the fruits are more likely to be attributed to environmental effects than genotypes, suggesting the need for further studies.

In conclusion, ISSR and RAPD markers proved to be technically suited for characterizing raw material used in the production of Huasco extra virgin oil for the purposes of Denomination of Origin (DO). These were particularly efficient to detect differences between other oil varieties, which may be used in the future as an alternative method of certification.

\section{ACKNOWLEDGEMENTS}

This research was financed by the Regional Innovation Assignment Fund for Regional Competitiveness (FIC Regional, 2015), from the Atacama Government, Code FIC-1504 (BIP 30432984-0) "ADN Vegetal de Atacama".

\section{LITERATURE CITED}

Antúnez, A., E. Cajías, L.F. Román, and M. González. 2014. Riego y producción de olivos en el Valle de Azapa. Boletín INIA $\mathrm{N}^{\circ}$ 292. 92 p. Instituto de Investigaciones Agropecuarias, INIA Ururi, Arica, Chile.

Arnan, X., B.C. López, J. Martínez-Vilalta, M. Estorach, and R. Poyatos. 2012. The age of monumental olive trees (Olea europaea) in northeastern Spain. Dendrochronologia 30:11-14.

Barranco, D., A. Cimato, P. Fiorino, L. Rallo, A. Touzani, C. Castañeda, et al. 2000. World Catalogue of Olive Varieties. International Olive Oil Council (IOOc), Madrid, Spain.

Barazani, O., Y. Waitz, Y. Tugendhaft, M. Dorman, A. Dag, M. Hamidat, et al. 2017. Testing the potential significance of different scion/ rootstock genotype combinations on the ecology of old cultivated olive trees in the southeast Mediterranean area. BMC Ecol. 17:3.

Baye, M.T., T. Abebe, and R.A. Wilke. 2011. Genotype-environment interactions and their translational implication. Personalized Medicine 8:59-70.

Belaj, A., Z. Satovic, L. Rallo, and I. Trujillo. 2004. Optimal use of RAPD markers for identifying varieties in olive (Olea europea L.) germplasm collections. J. Amer. Soc. Hort. Sci. 129:266-270

Busconi, M., L. Sebastiani, and C. Fogher. 2006. Development of SCAR markers for germplasm characterisation in olive tree (Olea europea L.). Mol. Breed. 17(1):59-68. 
Claros, M.G., R. Crespillo, M.L. Aguilar, and F.M. Cánovas. 2000. DNA fingerprinting and classification of geographically related genotypes of olive-tree (Olea europaea L.). Euphytica 116(2):131-142.

Contreras, R., and F. Tapia. 2016. Identificación genética de la variedad de olivo (Olea europaea L.) Sevillana y su relación con variedades productivas existentes en la provincia del Huasco. IDESIA (Chile) 34(3):15-22

ChileOliva. 2015. Informe anual del mercado nacional de aceite de oliva. Disponible en:www.chileoliva.cl/wp-content/ uploads/2017/04/INFORME-ANUALMERCADO-NACIONAL-DE-ACEITE-DEOLIVA-2015.pdf (Consulta 04 noviembre 2017).

Doyle, J.J., and J.L Doyle. 1987. A rapid DNA isolation procedure for small quantities of fresh leaf tissue. Focus 12:13-15.

Fabbri, A., G. Bartolini, M. Lambardi, and S. Kailis. 2004. Olive propagation manual. CSIRO Publishing, Melbourn, Australia.

Fuentes, E., F. Paucar, F. Tapia, J. Ortiz, P. Jimenez, and N. Romero. 2018. Effect of the composition of extra virgin olive oils on the differentiation and antioxidant capacities of twelve monovarietals. Food Chem. 243:285294

Gemas, V.J.V., M.C. Almadanim, R. Tenreiro, A. Martins, and P. Fevereiro. 2004. Genetic diversity in the olive tree (Olea europaea L. subsp. europaea) cultivated in Portugal revealed by RAPD and ISSR markers. Gen. Resour. Crop Evol. 51:501-511.

Hammer, Ø., D.A.T Harper, and P.D. Ryan. 2001. PAST: paleontological statistics software package for education and data analysis. Palaeontologia Electronica 4(1):1-9.

Hashiguchi, U.P. 2005. Formulación de un producto moldeado a base de pasta de aceituna: Aceituna Duquesa. Tesis de pregrado para optar al título de Ingeniero de Alimentos. Facultad de Ciencias Químicas y Farmacéuticas. Universidad de Chile. Santiago, Chile.

Hidalgo, J. 1993. Algunas notas para la historia del olivo en Arica (Chile). IDESIA 12:31-50.

INAPI. 2017a. ¿Cuáles son los principales requisitos para solicitar una IG o una DO?. Disponible en: http://www.inapi.cl/ portal/orientacion/602/w3-article-1794.html (Consulta 08 Noviembre 2017).

INAPI. 2017b. Aceite de oliva extra virgen del Valle del Huasco. Disponible en: http:// www.sellodeorigen.cl/611/w3-article-3048. html (Consulta 04 Noviembre 2017).
International Olive Oil Council (IOOC). 2017. Lists of production. Available at http://www. internationaloliveoil.org/estaticos/view/131world-olive-oil-figures (Accessed 13 March 2018).

Koehmstedt, A.M., M.K. Aradhya, D. Soleri, J.L. Smith, and V.S. Polito. 2010. Molecular characterization of genetic diversity, structure, and differentiation in the olive (Olea europaea L.) germplasm collection of the United States Department of Agriculture. Genet. Resour. Crop Evol. 58:519-531.

Linos, A., N. Nikoloudakis, A. Katsiotis, and M. Hagidimitriou. 2014. Genetic structure of the Greek olive germplasm revealed by RAPD, ISSR and SSR markers. Scientia Horticulturae 175:33-43.

Lynch, M., and M.G. Milligan. 1994. Analysis of population genetic structure with RAPD markers. Mol. Ecol. 3(2):91-99

Martins-Lopes, P., J. Lima-Brito, S. Gomes, J. Meirinhos, L. Santos, and H. Guedes-Pinto. 2007. RAPD and ISSR molecular markers in Olea europaea L.: Genetic variability and molecular cultivar identification. Gen. Resour. Crop Evol. 54(1):117-128.

Molina, M. 2015. El cultivo del olivo en la América colonial. Chronica Nova 41:121-142.

Montemurro, C., R. Simeone, A. Pasqualone, E. Ferrara, and A. Blanco. 2005. Genetic relationships and cultivar identification among 112 olive accessions using AFLP and SSR markers. Journal of Horticultural Science and Biotechnology 80(1):105-110.

Montemurro C., M.M. Miazzi, A. Pasqualone, V. Fanelli, W. Sabetta, and V. di Rienzo. 2015. Traceability of PDO olive oil 'Terra di Bari' using high resolution melting. J. Chem. 2015:496986.

Noormohammadi, Z., H. Samadi-Molayousefi, and M. Sheidai. 2012. Intra-specific genetic diversity in wild olives (Olea europaea ssp cuspidata) in Hormozgan Province, Iran. Gen. Mol. Res. 11(1):707-716

Padula, G., E. Giordani, E. Bellini, A. Rosati, S. Pandolfi, A. Paoletti, et al. 2008. Field evaluation of new olive (Olea europaea L.) selections and effects of genotype and environment on productivity and fruit characteristics. Advances in Horticultural Science 22:87-94.

Pasqualone, A., C. Montemurro, C. Summo, W. Sabetta, F. Caponio, and A. Blanco. 2007. Effectiveness of microsatellite DNA markers in checking the identity of protected designation of origin extra virgin olive oil. J. Agric. Food Chem. 55:3857-3862. 
Peakall, R., and P.E Smouse. 2012. GenAlEx 6.5: genetic analysis in Excel. Population genetic software for teaching and research - an update. Bioinformatics 28:2537-2539.

Pérez-López, D., F. Ribas, A. Moriana, H.F. Rapoport, A. De Juan. 2008. Influence of temperature on the growth and development of olive (Olea europaea L.) trees. Journal of Horticultural Science and Biotechnology 83:171-176

Romero, N., J. Saavedra, F. Tapia, B. Sepúlveda, and R. Aparicio. 2015. Influence of agroclimatic parameters on phenolic and volatile compounds of Chilean virgin olive oils and characterization based on geographical origin, cultivar and ripening stage. J. Sci. Food Agric. 96(2):583-592

Romo, R., M. Lagos, and J. Gil. 2015. Market values for olive oil attributes in Chile: a hedonic price function. Br. Food J. 117(1):358370.

Sesli, M., and E.D. Yegenoglu. 2017. Genetic relationships in wild olives (Olea europaea ssp. oleaster) by ISSR and RAPD markers. Biotechnology \& Biotechnological Equipment 31(5):897-904.

Sotomayor, E. 2000. Descripción del cultivar "Azapa" Olea europaea L. del Valle de Azapa. IDESIA (Chile) 18:61-66.
Tapia, F., M. Astorga, A. Ibacache, L. Martínez, C. Sierra, C. Quiroz, et al. 2003. Requerimientos de clima y suelo. p. 11-20. En Manual del Cultivo del Olivo. Boletín INIA N ${ }^{\circ} 101$. Instituto de Investigaciones Agropecuarias, INIA Intihuasi, La Serena, Chile.

Tapia, F., V. Arancibia, D. Larrea, S. Santelices, V. Araniti, M. Bauzá, et al. 2015. Producción de aceite de oliva Blend variedad Sevillana como base para la denominación de origen de aceite de oliva del Valle del Huasco. 62 p. Boletín INIA $\mathrm{N}^{\circ}$ 318. Instituto de Investigaciones Agropecuarias, INIA Intihuasi, La Serena, Chile.

Williams, J.G., A.R. Kubelik, K.J. Livak, J.A. Rafalski, and S.V. Tingey. 1990. DNA polymorphisms amplified by arbitrary primers are useful as genetic markers. Nucleic Acids Res. 18:6531-6535.

Ye, Y.M., J.W. Zhang, G.G. Ning, and M. Z. Bao. 2008. A comparative analysis of the genetic diversity between inbred lines of Zinnia elegansusing morphological traits and RAPD and ISSR markers. Scientia Horticulturae 118(1):1-7.

Zietkiewicz, E., A. Rafalski, and D. Labuda. 1994. Genome fingerprinting by simple sequence repeat (SSR)-anchored polymerase chain reaction amplification. Genomics 20:176-183. 